\title{
The Influence of Principal's Leadership and Teacher's Professionalism on Teacher's Performance at Muhammadiyah Private Junior High School in Medan
}

\author{
Muhammad Yakub ${ }^{1}$, Zainuddin ${ }^{2}$, Harun Sitompul ${ }^{3}$ \\ 1,2,3 Education Management Program, Universitas Negeri Medan \\ *Corresponding author. Email: myakub1306@gmail.com
}

\begin{abstract}
This research discussed about the effect of principal's leadership and teacher's professionalism on teacher's performance at Muhammadiyah Private Junior High School in Medan. The research method used is quantitative research with a path analysis approach which the population was 380 people and the total sample was 195 people by using the Harry King Nomogram. The sampling technique used proportional random sampling. The research respondents were teachers of Muhammadiyah Private Junior High School in Medan and 195 people as the sample. The data collection techniques used the Likert scale model instrument. Based on the research, it found that the influence of principal's leadership on teacher's performance was 0.164 , the effect of professionalism on teacher's performance was 0.178 , and the influence of the principal's leadership on teacher's professionalism was 0.362. From the result, it shown that the influence of principal's leadership and teacher's professionalism had a significant effect on teacher's performance. The efforts to improve teacher's performance will be successful through improving the principal's leadership and increasing teacher's professionalism.
\end{abstract}

Keywords: : Principal's Leadership, Teacher's Professionalism, Teacher's Performance.

\section{INTRODUCTION}

Educational renewal is a deliberate change to improve the ability of educators and education personnel to achieve certain goals in education. To achieve the vision, mission, and goals of the school, the role of the teacher as an educator is one of the most important elements in the implementation of education in schools.

The principal as the manager of the education unit with all his wishes, his ability is obliged to improve the enthusiasm of teachers and school employees to work well, build a vision and mission, establish good relationships with teachers, school staff, and students to develop and implement the 2013 Curriculum.

Regulation of the Republic of Indonesia No.19/2005 concerning about National Education Standards states that the management of education units at the primary and secondary education levels implements school-based management which is shown by independence, partnership, participation, openness and accountability.
The principal and teachers contribute to efforts in improving school quality. Principals and teachers as the necessary human resources should be of high quality, reliable and professional so that they can produce high quality education.

Moreover, the principal as the direct leader is a real example in the work activities of his subordinates [1]. Then,

Regulation of the Minister of National Education No.13/2007 regarding the standards of school/ madrasah principals explains that principals must have the dimensions of personality, management, entrepreneur, supervisory and social competencies.

One of the important duties of the principal is how a principal can optimally carry out school reforms in developing supervision of the performance of educators and education as an effort to increase productivity.

The concept of performance is generally always associated with a person's behavior or work. The definition of performance includes behavior that is under 
the control of employees, but places boundaries where the behavior is (and is not) relevant to job performance [2].

The principal's leadership and professional teachers will produce good teacher's performance as evidenced by student graduates or maximum student learning outcomes in accordance with school expectations. Principal's leadership is the main factor that encourages teachers to work professionally in improving their performance and it hoped that increasing teacher performance will increase student learning outcomes optimally.

Furthermore, it is necessary to conduct research to prove the assumption, is it true that the factors that influence the teacher's performance are the leadership of the principal and teacher's professionalism? So, it would find out how far the level of significant influence the principal's leadership and teacher's professionalism on teacher's performance.

\section{REVIEW OF LITERATURES}

\subsection{The Principal's Leadership}

Leadership is a social process with individual or groups that affect common goals, leadership is widespread in organizations both formally and informally and has rational, social, and emotional foundations [3].

Leadership is the ability to influence others so that people are passionately trying to achieve goals [4]. In decision making, leaders can use a different approach, which is highly depended on the leadership pattern applied by the leader [5].

The same opinion is expressed by another expert that a leader is seen as a person who has power, because he is able to influence his staff [6]. These strengths include: reward power, coercive power, expert power, legitimate power, and referent power. Furthermore, the success of a principal in managing a school is determined by two factors, namely: (1) the ability to innovate, such as the courage to do something new, identify various needs, and take advantage of opportunities in achieving school's goals; and (2) the level of efficiency and effectiveness that can be achieved in the movement of the school organization they lead [1].

One approach related to principal leadership that can be enforced is how the principal influences teachers so that the implementation of conducive learning activities in school can be happened. In this case, what the principal does is likely to show his behavior to teachers and staff. The leadership of the principal has a strategic role in his school, because as a leader, the principal is responsible for the implementation of the learning process in the school.

\subsection{The Teacher's Professionalism}

Teaching profession is a form of work that must be adapted to the changes and developments of the times [1]. The improvement of the teacher's quality must always be carried out to adapt to the developments and changes of the times. Therefore, the professionalization efforts must continue to be paid attention by teachers in order to become the real profession. A teacher professionally is a profession/position or job that requires special expertise, because this type of profession or job cannot be done by just anyone, whose position is outside the field of education.

Professional refers to people who carry out a profession with a minimum education of S1 and follow the professional education or pass a professional exam [7]. The term professionalism means people who carry out a profession by using it as a livelihood. Professionalism is an understanding that teaches that every job must be done professionally by professional people.

Teachers are professional educators with the main task of educating, teaching, guiding, directing, training, assessing, and evaluating. A teacher is said to be a professional if he/she has expertise, skills or abilities that meet certain quality standards or norms and requires professional education.

The teacher as a learning agent has the role to facilitate students so that they can learn comfortably and succeed in mastering predetermined competences. There are four main competences that teachers must master as learning agents, namely: (1) personality competence; (2) pedagogical competence; (3) professional competence; and (4) social competence [8]. Finally, they can act as a facilitator, motivator, and inspirer for students.

\subsection{The Teacher's Performance}

Teachers as educators in schools have a central position to make changes towards achieving the vision, mission, and goals of the school that have been set. The education process in a school will run well if it is supported by good teacher performance.

In order to measure the success of teachers in carrying out their professional duties can be measured from the teacher's performance criteria which include teaching skills, guiding, assessing, using teaching aids, socializing and communicating with students and skills in preparing teaching planning [9].

The assessment of teacher's performance is carried out annually by the principal or supervisors or senior teachers appointed by the school principal. Assessment of teacher's competence is carried out with certain instruments (learning, mentoring, or other additional tasks relevant to school/madrasah functions), namely: 

a. Ability to plan and prepare for teaching
b. Mastering the teaching methods and strategies
c. Giving assignments to students
d. Class management skills
e. Ability to do assessment and evaluation

The implementation of school programs and activities such as the teaching and learning process to obtain the expected quality requires serious supervision by the principal. The principal must be able to carry out internal supervision of all activities in the school he leads. The principal supervises in ensuring whether the teacher carries out his duties in accordance with school goals that refer to the regulations set by the government. Thus, it is hoped that teacher's performance can increase in the process of teaching and learning activities in the classroom by producing the best student's learning achievement.

\subsection{The Direct Effect of Principal's Leadership on Teacher's Performance}

A principal as a leader in a school must be able to understand and take positive actions so that teachers improve their performance, because the teacher as an educator in schools is one of the human resources who has a strategic role to achieve the school's goals.

The principal needs to find out how far the teacher's performance in carrying out their duties, he must regularly supervise and evaluate the teacher's performance. Teachers as learning agents at all levels of education must have the following competences: (1) pedagogical competence; (2) personality competence; (3) professional competence; and (4) social competence.

The principal must be able to carry out internal supervision of all activities in the school he leads. Based on the explanation above, it can be assumed that the leadership of the principal has a direct effect on the performance of teachers at Muhammadiyah Private Junior High School in Medan.

\subsection{The Direct Effect of Teacher's Professionalism on Teacher's Performance}

Professionalism can be interpreted as a view to always think, behave and work seriously, work hard, work full time, be disciplined, be honest, be loyal and dedicate to the success of their work.

Professional teachers must be experts in the field of theory and practice, master the knowledge being taught and at the same time experts in the field of education. Professional teachers will show a rational appearance in carrying out their duties in educating. Professional teachers are teachers who are able to teach students and are able to have the right strategy, so that the results are satisfying because students succeed in increasing their learning outcomes maximally.

Professional teachers in carrying out their service duties, should be based on encouragement from within themselves because they feel called to fulfill their duties. If a teacher who loves his students, loves his job, and feels responsible for his job, it means that the teacher loves his profession, of course, it will have a positive effect on his performance. In connection with this description, it can be assumed that the teacher's professionalism has a direct effect on teacher's performance.

\section{METHOD}

This research used survey with a path analysis approach that analyzed the principal's leadership and teacher's professionalism on teacher's performance. Path analysis is a quantitative analysis as a development of multiple linear regression, which aimed to find direct and indirect effects in the relationship between variables through intermediate variables. This research method was classified as ex post facto research. Ex post facto research is research conducted to examine events that have occurred and then trace back to find out the factors that caused these incidents [10].

It examined and analyzed the effect of one variable on other variables, namely: principal's leadership (X1), teacher's professionalism (X2), and teacher's performance (Y) which conducted at Muhammadiyah Private Junior High School in Medan for three months (June, July, and August 2020). Then, the population of this research were all teachers who teach at Muhammadiyah Private Junior High School in Medan who met the qualifications of educators in accordance with the government regulations in Indonesia (380 teachers spread across 15 schools).

The technique of determining the sample used proportional random sampling technique or sampling technique randomly and proportionally. The sample size used an error rate or degree of error $\alpha=0.05$ or $5 \%$ which the samples were 195 teachers.

Moreover, the data collection technique used survey by distributing questionnaires to samples teachers for the principal's leadership variable (X1), teacher's professionalism (X2), on the teacher's performance variable (Y) using teacher's performance assessment filled in by the principal or vice principal during the observation. Each instrument is equipped with measurement objectives, filling instructions, and a scale of assessment using a scale of five with assigned values adjusted to the context of the statements filled in by the teacher. Then, in order to analyze the data, it used descriptive and inferential statistical analysis techniques. 


\section{RESULTS AND DISCUSSION}

After analyzing the data, it found the result as in the following Table 1 .

Table 1. Summary of descriptive statistics calculation results

\begin{tabular}{|l|c|c|c|}
\hline \multirow{2}{*}{ Statistics } & \multicolumn{3}{|l|}{ Variable Data } \\
\cline { 2 - 4 } & X1 & X2 & Y \\
\hline Sample & 195 & 195 & 195 \\
\hline $\begin{array}{l}\text { Ideal Highest } \\
\text { Score }\end{array}$ & 180 & 155 & 200 \\
\hline $\begin{array}{l}\text { Ideal Lowest } \\
\text { Score }\end{array}$ & 36 & 31 & 40 \\
\hline Ideal Mean & 108.000 & 93.000 & 114.000 \\
\hline $\begin{array}{l}\text { Ideal Standard } \\
\text { Deviation }\end{array}$ & 24.000 & 20.667 & 25.333 \\
\hline Highest Score & 173 & 147 & 181 \\
\hline Lowest Score & 72 & 75 & 82 \\
\hline Range & 101 & 72 & 99 \\
\hline Class Length & 12 & 9 & 12 \\
\hline Many Classes & 9 & 9 & 9 \\
\hline Mode & 130.587 & 120.420 & 134.000 \\
\hline Median & 118.462 & 135.959 \\
\hline Mean & 122.650 & 127.674 \\
\hline Deviation & 19.098 & 19.194 \\
\hline
\end{tabular}

Furthermore, the result of the ideal mean and ideal standard deviation are classified into four categories, namely: poor, low, medium, and high categories with the following conditions:

If $\mathrm{X}:<\mathrm{Mi}-1.5 \mathrm{SDi}=$ category tends to be less

If $\mathrm{X}: \mathrm{Mi}-1.5 \mathrm{SDi}$ to $\mathrm{Mi}=$ category tends to be low

If $\mathrm{X}:>\mathrm{Mi}$ to $\mathrm{Mi}+1.5 \mathrm{SDi}=$ the category tends to be medium

$$
\text { If } \mathrm{X}:>\mathrm{Mi}+1.5 \mathrm{SDi}=\text { category tends to be high }
$$

Based on the data in Table 1, it showed that the ideal mean of the principal's leadership variable was 108.000; the ideal lowest score was 36; the ideal highest score was 180; and an ideal standard deviation was 24.000. Meanwhile, the mean or average score for the measurement of the principal's leadership variable obtained was 130.595; with the lowest score obtained was 72 ; highest score was $173 ; 127.750$ for mode; median was 130.587 ; and standard deviation was 19.038 .
Then, the ideal mean of teacher's professionalism variable was 93.000; the lowest ideal score was 31; the ideal highest score was 155 ; with the ideal standard deviation was 20.667. The mean score of the measurement result was 118.462 ; lowest score was 75 ; highest score was $147 ; 122.650$ for mode; median was 120.420; and standard deviation was 16.098.

For the teacher's performance variables, the ideal mean was 120.000; lowest ideal score was 40; the ideal highest score was 200; and the ideal standard deviation was 26.667. The mean result of the measurement of teacher's performance variables was 134.210; lowest score was 74; highest score was 169; mode was 136.265; median was 136.750; and 21.629 for the standard deviation.

The result showed that the influence of the principal's leadership on teacher's professionalism was significant, where the influence was $36.2 \%$. This condition was in accordance with several experts such as those synthesized by Wayne and Cecil (2014), Gibson, Donnely and Ivancevich (2012), and Durbin [11]. The principal's leadership could be directly related to professionalism and would achieve goals if the principal's leadership can influence individual, groups or organizations to work professionally.

The leadership of the principal must be able to strive for teachers and staff to become professional people so that they are willing to accept their influence and do something to help the process of achieving the goals of the school organization.

\section{CONCLUSION}

Based on the result, it concluded that the leadership of the principal has a positive and significant direct effect on the teacher's performance at Muhammadiyah Private Junior High School in Medan with a coefficient value was 0.164 . The indicator of the principal's leadership variable that has the greatest influence is guidance and direction. In other words, if the aspect of guidance and direction is better, the teacher's performance at Muhammadiyah Private Junior High School in Medan City will be higher.

Furthermore, the teacher's professionalism has a positive and significant direct effect on the teacher's performance at Muhammadiyah Private Junior High School in Medan with a coefficient value was 0.178 . The indicator of the teacher's professionalism variable that has the greatest influence was expert in the field of theory and practice. In other words, if the expert aspects in the field of theory and practice is better, the teacher's performance will be higher.

The effort in improving the principal's leadership can be done by optimizing the dimensions of guidance and direction. Improvement in the aspect of guidance and 
direction can be done continuously by always making changes in a positive direction according to developments in science and technology. Moreover, the effort to improve the teacher's professionalism can be done by optimizing the expert dimension in the field of theory and practice. Improvement of the expert aspects in the field of theory and practice can be done by attending trainings and having higher levels of education.

\section{REFERENCES}

[1] Mukhtar, Iskandar, Orientasi Baru Supervisi Pendidikan. Jakarta: Gaung Persada, 2009.

[2] Colquit, Jason. A., Jeffery. A. L., and Michael L, and Wesson, Organizational Behavior, Improving Performance and Commitment in the Workplace. New York: McGraw Company, 1995.

[3] Wayne, K. H., Cecil, G., and Miskel, Administrasi Pendidikan: Teori, Riset, dan Praktik. Yogyakarta: Pustaka Pelajar, 2014.

[4] Gibson, J. L., Ivancevich, J. M., and Donnelly, J. H., Organizational: Behavior, Structure, Processes. New York: McGraw-Hill, 2012.

[5] Syafaruddin, Manajemen Mutu Terpadu Dalam Pendidikan, Konsep, Strategi, dan Aplikasi. Jakarta: Gramedia Widiasarana Indonesia, 2002.

[6] Owens, R. G, Organizational Behavior in Education. Boston: Allyn and Baccon, Inc, 1991.

[7] Budiman, N. N., Etika Profesi Guru. Yogyakarta: Mentari Pustaka, 2013.

[8] Mulyana, A. Z., Rahasia Menjadi Guru Hebat. Jakarta: PT Grasindo, 2010.

[9] Sudarman, D., Profesionalisasi dan Etika Profesi Guru. Bandung: Alfabeta, 2013.

[10] Sugiyono, Metode penelitian Administrasi. Bandung: Alfabeta, 2011.

[11] Durbin, A. J., Leadership: Reseach Findings, Practices and Skills, Third Edition. Boston: Houghton Miflin Company, 2001. 